\title{
UJI AKTIVITAS ANTIOKSIDAN EKSTRAK AIR DAN EKSTRAK METANOL BEBERAPA VARIAN BUAH KENITU (Chrysophyllum cainito L.) DARI DAERAH JEMBER
}

\author{
Moch. Amrun H.*+, Umiyah**, dan Evi Umayah U* \\ * Bagian Biologi Farmasi, Program Studi Farmasi Universitas Jember \\ ** Jurusan Biologi, FMIPA Universitas Jember \\ + korespondensi : amrun@farmasi.unej.ac.id
}

\begin{abstract}
Star apple or Chrysophyllum cainito L., family Sapotaceae; which is indigenous in Central America has been grown locally arround Jember, East Java. Ethnobotanical data exhibits its medicinal properties such as: soothing inflammation in laringitis and pneumonia, treatment for diabetes mellitus and cancer remedy which are related to free radical mechanism. Therefore, it is necessary to determine its free radical scavenger activity.

There are three types of Jember's star apple fruit (local name: kenitu): big size, green color with round shape (kenitu hijau bulat); medium size, green color with oval shape (kenitu hijau lonjong); and small size, red purplish color with round shape (kenitu merah bulat). Previous research shown that both water and methanol extracts of kenitu hijau lonjong has DPPH free radical scavenger activity as its antioxidant capacity. In recent research the DPPH free radical scavenger activity was performed on both water and methanol extract of these three types of kenitu. The results showed that kenitu merah bulat exhibits the highest antioxidant activity of these three types with $I C_{50}=426.118$ and 169.094 ppm for methanol and water extracts sequentially in $60^{\text {th }}$ minutes.
\end{abstract}

Key words: star apple, Chrysophyllum cainito L., free radical scavenger, DPPH, $I C_{50}$

\section{PENGANTAR}

Senyawa antioksidan memiliki peran yang sangat penting dalam kesehatan. Berbagai bukti ilmiah menunjukkan bahwa senyawa antioksidan mengurangi risiko terhadap penyakit kronis seperti kanker dan penyakit jantung koroner. Karakter utama senyawa antioksidan adalah kemampuannya untuk menangkap radikal bebas (Prakash, 2001). Radikal bebas adalah molekul yang sangat reaktif karena memiliki elektron yang tidak berpasangan dalam orbital luarnya sehingga dapat bereaksi dengan molekul sel tubuh dengan cara mengikat elektron molekul sel tersebut (Wijaya, 1996). Radikal bebas tersebut dapat mengoksidasi asam nukleat, protein, lemak, bahkan DNA sel dan menginisiasi timbulnya penyakit degeneratif (Leong dan Shui, 2001). Senyawa antioksidan yang dihasilkan dari tumbuhan seperti vitamin $\mathrm{C}$, vitamin $\mathrm{E}$, karoten, golongan fenol terutama polifenol, dan flavonoid diketahui berpotensi mengurangi risiko penyakit degeneratif tersebut (Prakash, 2001; Okawa et al., 2001).

Tanaman kenitu (Star Apple), Chrysophyllum cainito L. famili Sapotaceae banyak terdapat di Pulau Jawa bagian hilir dan daerah pegunungan rendah. Tanaman ini pernah dibiakkan sebagai tanaman buah-buahan atau tanaman hias. Di dalam buletin No. 37 Musium Kolonial, Kwast mendeskripsikan buah kenitu sebagai buah yang lembut, berair, menyegarkan, dan enak rasanya. Akan tetapi, buah tersebut tidak laku dijual di sini bahkan juga di tempat asalnya di Amerika tropis (Heyne, 1987). Walaupun demikian, di tempat lain tanaman kenitu bermanfaat dalam pengobatan berbagai penyakit yang terkait baik secara langsung maupun tidak langsung dengan radikal bebas. Infus daun yang kaya akan tanin dipercaya oleh masyarakat Kuba di Miami sebagai obat kanker. Buah yang sudah masak digunakan sebagai antiinflamasi pada keadaan laringitis dan pneumonia serta pengobatan diabetes melitus (Morton, 1987).

Isolasi senyawa aktif yang dipandu oleh uji aktivitas (activity test guided isolation) antiradikal bebas DPPH dilakukan terhadap buah kenitu yang tumbuh di Florida Selatan, Amerika Serikat; serta didapatkan sembilan senyawa polifenol yang bersifat sebagai antioksidan (Luo et al., 2002). Metode aktivitas antiradikal bebas DPPH merupakan metode terpilih untuk menapis aktivitas antioksidan bahan alam (Molyneux, 2004; Luo et al., 2002; Leong dan Shui, 2002; Okawa et al., 2001; Santosa et al., 1998). Pada tahun 2004 dilakukan uji aktivitas antiradikal bebas DPPH terhadap ekstrak metanol dan ekstrak air buah kenitu yang tumbuh di daerah Jember, Jawa Timur dan diketahui kedua ekstrak tersebut memiliki aktivitas antiradikal bebas DPPH (Hidayat dan Umiyah, 2005). 
Di Pulau Jawa, terdapat dua jenis kenitu (sawo durian) yang dapat dibedakan dari daun dan buahnya, yakni kenitu merah dan kenitu hijau (Anonim, 1994; Verheij dan Coronel, 1992). Berdasarkan hasil observasi tentang buah kenitu Jember, diketahui terdapat dua macam kenitu yaitu kenitu hijau (buah bentuk bulat dan buah bentuk elips) dan satu jenis kenitu merah (buah bentuk bulat). Pada penelitian sebelumnya dilakukan uji antioksidan terhadap ekstrak air dan ekstrak metanol yang berasal dari satu jenis buah kenitu hijau dengan buah bentuk lonjong saja sehingga perlu dilakukan penelitian lanjutan untuk menguji aktivitas antioksidan ekstrak air dan ekstrak metanol varian buah kenitu lainnya yang tumbuh di daerah Jember. Diharapkan penelitian ini akan memberikan informasi dasar tentang aktivitas antioksidan berbagai varian buah kenitu Jember.

\section{BAHAN DAN CARA KERJA}

\section{Bahan dan Alat yang Digunakan}

Bahan penelitian adalah buah kenitu (Chrysophyllum cainito L.) yang diperoleh dari daerah Jember yang dideterminasi menurut USDA (2004); DPPH (1,1-difenil2-pikril hidrazil hidrat) ex. Sigma; pelarut metanol dan etanol untuk Spektrofotometer ex. E.Merck. Alat yang digunakan Spektrofotometer Hitachi U1800, Mikroskop Meiji T450, kamera digital Nikon Coolpix 4300, Freeze dryer; dan Rotavapor Buchi.

\section{Identifikasi Makroskopis Daun dan Buah}

Diamati bentuk, tekstur, dan warna bagian atas dan bawah daun. Diamati bentuk, tekstur dan warna buah. Selanjutnya diambil gambarnya dengan kamera digital.

\section{Identifikasi Mikroskopis daun}

Dibuat preparat mikroskopis daun dengan menggunakan larutan kloralhidrat panas. Diamati anatomi mikroskopis daun (terutama fragmen-fragmen yang spesifik seperti trikom, stomata, dan lain sebagainya) dan diambil gambarnya dengan kamera digital.

\section{Pembuatan Ekstrak Metanol}

Ditimbang $1 \mathrm{~kg}$ daging buah kenitu segar, dimaserasi dua kali dengan metanol. Ampas dipisahkan, filtrat diuapkan di-rotavapor hingga kering atau pekat dan dicatat beratnya sebagai ekstrak metanol kasar. Ekstrak kemudian disuspensikan dalam air dan dipartisikan dengan heksana. Fraksi heksana dipisahkan, fraksi air diuapkan hingga kering dan dicatat beratnya sebagai ekstrak metanol.

\section{Pembuatan Ekstrak Air}

Ditimbang $1 \mathrm{~kg}$ daging buah kenitu segar dan dibleaching selama 15 menit untuk mendenaturasi enzim polifenol oksidase. Selanjutnya daging buah tersebut dikeringkan dengan teknik freeze drying dan dicatat beratnya sebagai ekstrak air.

\section{Pembuatan Larutan Uji}

Larutkan masing-masing ekstrak ke dalam pelarutnya untuk membuat larutan uji dalam berbagai konsentrasi.

\section{Pembuatan Larutan DPPH}

Ditimbang DPPH kristal dan dilarutkan dalam etanol tepat pada konsentrasi 0,004\% untuk segera digunakan dan dijaga pada suhu rendah serta terlindung cahaya.

\section{Pengujian Antiradikal Bebas DPPH}

Pengujian antiradikal bebas DPPH (Santosa et al., 1998; Dyatmiko dan Santosa, 1998) dilakukan sebagai berikut: dipipet $600 \mu \mathrm{l}$ pelarut (metanol, air) ke dalam kuvet dan ditambahkan larutan DPPH ad $3 \mathrm{ml}$ dan diaduk rata dengan pipet. Selanjutnya segera dibuat spektra sinar tampak pada panjang gelombang $(\lambda)$ 400-600 $\mathrm{nm}$. Dicatat absorban pada $\lambda$ : 497-517-537 $\mathrm{nm}$. Untuk pengukuran antiradikal bebas bahan uji digunakan metode yang sama, hanya saja pelarut diganti dengan larutan uji (ekstrak metanol, ekstrak air). Dicatat absorban pada $\lambda$ : 497-517-537 $\mathrm{nm}$ pada menit ke-5 dan sekali lagi pada menit ke-60. Dilakukan prosedur yang sama untuk larutan uji dari jenis buah kenitu yang lain. Perhitungan kapasitas antiradikal bebas DPPH diukur dari peredaman warna ungu merah DPPH, yaitu puncak $517 \mathrm{~nm}$ dengan perhitungan sebagai berikut:

Absorban hitung $\lambda 517 \mathrm{~nm}=\mathrm{A}_{517}-\frac{\mathrm{A}_{497}+\mathrm{A}_{537}}{2}$

Perhitungan kapasitas antiradikal bebas sebagai persen peredaman absorban pada puncak $517 \mathrm{~nm}$ menggunakan perhitungan sebagai berikut:

$$
\% \text { peredaman DPPH }=1-\left(\frac{\text { A hitung bahan uji }}{\text { A hitung DPPH }}\right) \times 100 \%
$$

Nilai $0 \%$ berarti tidak mempunyai aktivitas antiradikal bebas atau antioksidan, sedangkan nilai $100 \%$ berarti peredaman total dan pengujian perlu dilanjutkan dengan pengenceran larutan uji untuk melihat batas konsentrasi 
aktivitasnya. Selanjutnya dibuat kurva linear antara konsentrasi larutan uji dengan \% peredaman DPPH dan ditentukan harga $\mathrm{IC}_{50}$, yakni konsentrasi larutan uji yang memberikan peredaman DPPH sebesar 50\%. Harga $\mathrm{IC}_{50}$ umum digunakan untuk menyatakan aktivitas antioksidan suatu bahan uji dengan metode peredaman radikal bebas DPPH (Molyneux, 2004).

\section{HASIL}

\section{Identifikasi Makroskopis Daun dan Buah}

Dari hasil pengamatan makroskopis sampel buah kenitu diperoleh hasil sebagai berikut: bentuk buah bulat dan lonjong, daging buah berwarna putih susu dengan serat yang kasar. Jika dilakukan irisan melintang terhadap buah maka kedudukan biji akan berbentuk seperti bintang, sesuai namanya: star apple. Pada perbatasan antara kulit buah dengan daging buah sering dijumpai getah berwarna putih. Permukaan daun bagian atas berwarna hijau tua dengan tekstur licin dan mengkilat seperti daun jeruk nipis, sedangkan permukaan bawah daun berwarna coklat tua dengan tekstur kasar.

\section{Identifikasi Mikroskopis Daun}

Hasil pengamatan mikroskopis daun dari ketiga varian kenitu tidak menunjukkan perbedaan yang signifikan. Dijumpai trikom berbentuk jarum kompas dan stomata tipe anomositik yang khas untuk buah kenitu.

\section{Pembuatan Ekstrak Metanol dan Ekstrak Air}

Pada pembuatan ekstrak metanol didapatkan ekstrak metanol dengan konsistensi seperti selai. Selain itu juga didapatkan ekstrak air dengan konsistensi seperti selai

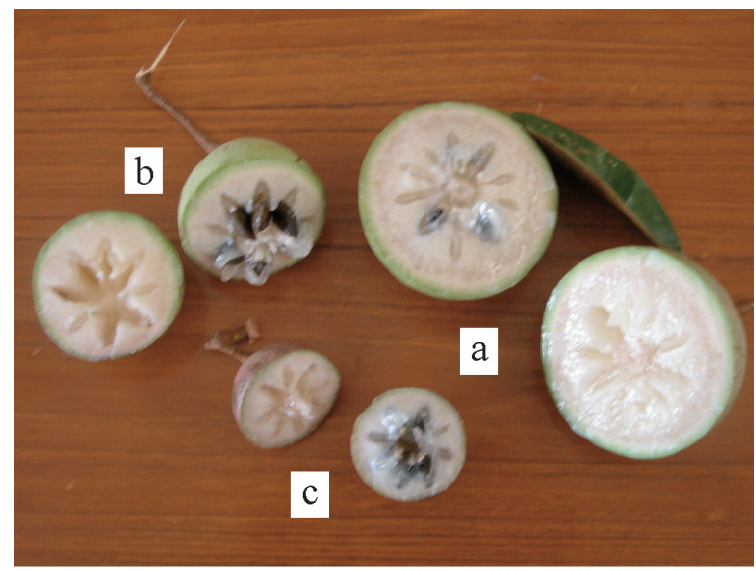

Gambar 1. Berbagai varian kenitu: a) hijau bulat, b) hijau lonjong dan c) merah bulat
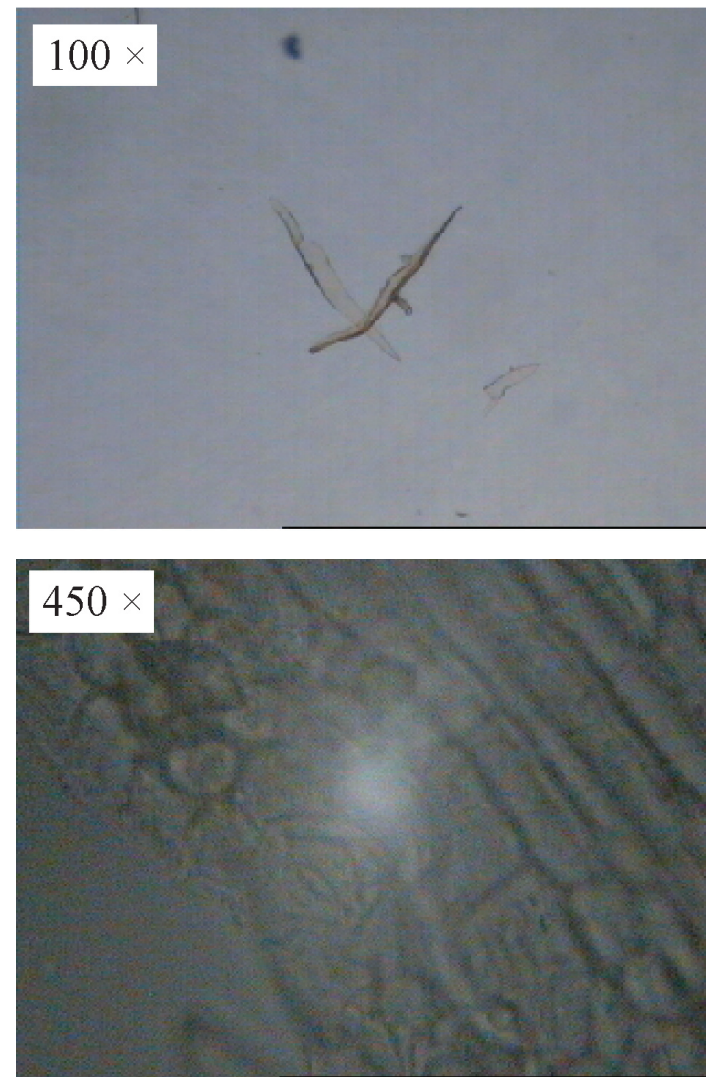

Gambar 2. Trikom dan stomata daun kenitu



Gambar 3. Contoh kurva peredaman DPPH ekstrak metanol kenitu hijau bulat menit ke-60 (A = DPPH, B = larutan uji 250 ppm)

seperti halnya ekstrak metanol. Selanjutnya masing-masing ekstrak dibuat larutan uji dengan kadar masing-masing 2000, 1000, 500, dan 250 ppm.

\section{Uji Antiradikal Bebas DPPH}

Pada pelaksanaan uji antiradikal bebas diawali dengan pembuatan spektra sinar tampak (400-600 nm) larutan uji 
untuk melihat apakah masih tampak adanya kurva normal (sigmoid) dengan puncak $517 \mathrm{~nm}$. Semua spektra larutan uji menunjukkan kurva normal dengan puncak $517 \mathrm{~nm}$. Contoh spektra larutan uji dapat dilihat Gambar 3.
Hasil pengujian antiradikal bebas berbagai varian buah kenitu dapat dilihat pada Tabel 1-7.

Harga $\mathrm{IC}_{50}$ dihitung berdasarkan persamaan regresi linier yang didapatkan dengan cara memplot konsentrasi

Tabel 1. Hasil pengujian antiradikal bebas ekstrak metanol kenitu hijau bulat

\begin{tabular}{|c|c|c|c|c|c|c|}
\hline Menit ke- & Sampel & $A_{497}$ & $A_{517}$ & $A_{537}$ & $A_{\text {hit }}$ & $\%$ peredaman \\
\hline \multirow[t]{5}{*}{5} & DPPH & 0,961 & 1,096 & 0,941 & 0,145 & \\
\hline & 2000 ppm & 0,533 & 0,585 & 0,499 & 0,069 & 52,41 \\
\hline & 1000 ppm & 0,620 & 0,695 & 0,594 & 0,088 & 39,31 \\
\hline & 500 ppm & 0,682 & 0,772 & 0,662 & 0,100 & 31,03 \\
\hline & 250 ppm & 0,754 & 0,857 & 0,736 & 0,112 & 22,76 \\
\hline \multirow[t]{4}{*}{60} & DPPH & 0,991 & 1,127 & 0,970 & 0,147 & \\
\hline & 1000 ppm & 0,584 & 0,647 & 0,553 & 0,079 & 46,42 \\
\hline & 500 ppm & 0,666 & 0,750 & 0,641 & 0,097 & 34,13 \\
\hline & 250 ppm & 0,758 & 0,860 & 0,739 & 0,112 & 23,89 \\
\hline
\end{tabular}

Tabel 2. Hasil pengujian antiradikal bebas ekstrak metanol kenitu hijau lonjong

\begin{tabular}{cllcccc}
\hline Menit ke- & Sampel & $\mathbf{A}_{\mathbf{4 9 7}}$ & $\mathbf{A}_{\mathbf{5 1 7}}$ & $\mathbf{A}_{\mathbf{5 3 7}}$ & $\mathbf{A}_{\text {hit }}$ & \% peredaman \\
\hline 5 & DPPH & 1,014 & 1,158 & 0,995 & 0,154 & \\
& $2000 \mathrm{ppm}$ & 0,329 & 0,337 & 0,283 & 0,031 & 79,80 \\
& $1000 \mathrm{ppm}$ & 0,498 & 0,546 & 0,464 & 0,065 & 57,65 \\
& $500 \mathrm{ppm}$ & 0,627 & 0,706 & 0,603 & 0,091 & 30,72 \\
60 & $250 \mathrm{ppm}$ & 0,710 & 0,805 & 0,690 & 0,105 & 0,164 \\
& DPPH & 1,095 & 1,249 & 1,075 & 0,003 & 98,17 \\
& $2000 \mathrm{ppm}$ & 0,172 & 0,144 & 0,110 & 0,051 & 69,21 \\
& $1000 \mathrm{ppm}$ & 0,436 & 0,464 & 0,391 & 0,083 & 49,70 \\
& $500 \mathrm{ppm}$ & 0,611 & 0,677 & 0,578 & 0,105 & 36,28 \\
\hline
\end{tabular}

Tabel 3. Hasil pengujian antiradikal bebas ekstrak metanol kenitu merah bulat

\begin{tabular}{cllcccc}
\hline Menit ke- & Sampel & $\mathbf{A}_{\mathbf{4 9 7}}$ & $\mathbf{A}_{\mathbf{5 1 7}}$ & $\mathbf{A}_{\mathbf{5 3 7}}$ & $\mathbf{A}_{\text {hit }}$ & \% peredaman \\
\hline 5 & DPPH & 1,252 & 1,314 & 1,094 & 0,141 & \\
& $2000 \mathrm{ppm}$ & 0,511 & 0,423 & 0,319 & 0,008 & 94,33 \\
& $1000 \mathrm{ppm}$ & 0,619 & 0,594 & 0,477 & 0,046 & 67,38 \\
& $500 \mathrm{ppm}$ & 0,806 & 0,818 & 0,672 & 0,079 & 3,97 \\
60 & $250 \mathrm{ppm}$ & 0,890 & 0,920 & 0,760 & 0,095 & 0,149 \\
& DPPH & 1,306 & 1,375 & 1,146 & 0,021 & 85,91 \\
& $1000 \mathrm{ppm}$ & 0,493 & 0,439 & 0,343 & 0,068 & 54,70 \\
& $500 \mathrm{ppm}$ & 0,752 & 0,750 & 0,613 & 0,091 & 38,93 \\
\hline
\end{tabular}

Tabel 4. Hasil pengujian antiradikal bebas ekstrak air kenitu hijau bulat

\begin{tabular}{|c|c|c|c|c|c|c|}
\hline Menit ke- & Sampel & $A_{497}$ & $A_{517}$ & $A_{537}$ & $A_{\text {hit }}$ & $\%$ peredaman \\
\hline \multirow[t]{5}{*}{5} & DPPH & 1,020 & 1,155 & 0,989 & 0,151 & \\
\hline & 2000 ppm & 0,891 & 0,874 & 0,772 & 0,043 & 71,76 \\
\hline & 1000 ppm & 0,893 & 0,941 & 0,847 & 0,071 & 52,82 \\
\hline & 500 ppm & 0,894 & 0,981 & 0,896 & 0,086 & 42,86 \\
\hline & 250 ppm & 0,899 & 1,010 & 0,923 & 0,099 & 34,22 \\
\hline \multirow[t]{5}{*}{60} & DPPH & 1,055 & 1,194 & 1,024 & 0,155 & \\
\hline & 2000 ppm & 0,979 & $0, .908$ & 0,794 & 0,022 & 86,08 \\
\hline & 1000 ppm & 0,979 & 0,988 & 0,877 & 0,060 & 61,17 \\
\hline & 500 ppm & 0,968 & 1,033 & 0,933 & 0,082 & 46,60 \\
\hline & 250 ppm & 0,970 & 1,060 & 0,958 & 0,096 & 37,86 \\
\hline
\end{tabular}


Tabel 5. Hasil pengujian antiradikal bebas ekstrak air kenitu hijau lonjong

\begin{tabular}{|c|c|c|c|c|c|c|}
\hline Menit ke- & Sampel & $A_{497}$ & $A_{517}$ & $A_{537}$ & $A_{\text {hit }}$ & $\%$ peredaman \\
\hline \multirow[t]{5}{*}{5} & DPPH & 0,983 & 1,115 & 0,955 & 0,146 & \\
\hline & 2000 ppm & 0,724 & 0,689 & 0,599 & 0,028 & 81,16 \\
\hline & 1000 ppm & 0,784 & 0,816 & 0,729 & 0,060 & 59,25 \\
\hline & 500 ppm & 0,816 & 0,891 & 0,809 & 0,079 & 46,23 \\
\hline & 250 ppm & 0,846 & 0,949 & 0,866 & 0,093 & 36,30 \\
\hline \multirow[t]{5}{*}{60} & DPPH & 1,050 & 1,189 & 1,020 & 0,154 & \\
\hline & 2000 ppm & 0,899 & 0,801 & 0,682 & 0,011 & 93,18 \\
\hline & 1000 ppm & 0,947 & 0,927 & 0,812 & 0,048 & 69,16 \\
\hline & 500 ppm & 0,925 & 0,964 & 0,864 & 0,069 & 54,87 \\
\hline & 250 ppm & 0,942 & 1,024 & 0,924 & 0,091 & 40,91 \\
\hline
\end{tabular}

Tabel 6. Hasil pengujian antiradikal bebas ekstrak air kenitu bulat merah

\begin{tabular}{|c|c|c|c|c|c|c|}
\hline Menit ke- & Sampel & $A_{497}$ & $A_{517}$ & $A_{537}$ & $A_{\text {hit }}$ & $\%$ peredaman \\
\hline \multirow[t]{5}{*}{5} & DPPH & 1,024 & 1,153 & 0,989 & 0,147 & \\
\hline & 2000 ppm & 0,825 & 0,735 & 0,632 & 0,007 & 95,56 \\
\hline & 1000 ppm & 0,889 & 0,844 & 0,736 & 0,032 & 78,50 \\
\hline & 500 ppm & 0,891 & 0,915 & 0,779 & 0,080 & 45,39 \\
\hline & 250 ppm & 0,910 & 0,979 & 0,884 & 0,082 & 44,03 \\
\hline \multirow[t]{4}{*}{60} & DPPH & 1,083 & 1,222 & 1,046 & 0,158 & \\
\hline & 500 ppm & 1,035 & 0,982 & 0,856 & 0,037 & 76,83 \\
\hline & 250 ppm & 1,015 & 1,038 & 0,926 & 0,068 & 57,14 \\
\hline & 125 ppm & 1,011 & 1,073 & 0,965 & 0,085 & 46,03 \\
\hline
\end{tabular}

larutan uji dengan \% peredaman puncak DPPH, sebagai parameter aktivitas antioksidan. Harga $\mathrm{IC}_{50}$ berbagai varian ekstrak kenitu dapat dilihat pada tabel di bawah ini.

Tabel 7. Harga $I C_{50}$ berbagai ekstrak kenitu

\begin{tabular}{clr}
\hline Menit ke- & \multicolumn{1}{c}{ Sampel } & IC $_{50}$ (ppm) \\
\hline 5 & Ekstrak air kenitu hijau bulat & 919,324 \\
& Ekstrak air kenitu hijau lonjong & 707,430 \\
& Ekstrak air kenitu merah bulat & 431,597 \\
& Ekstrak metanol kenitu hijau & 1783,292 \\
& bulat & \\
& Ekstrak metanol kenitu hijau & 847,243 \\
& lonjong & \\
& Ekstrak metanol kenitu merah & 664,097 \\
& bulat & \\
& Ekstrak air kenitu hijau bulat & 645,882 \\
& Ekstrak air kenitu hijau lonjong & 427,368 \\
& Ekstrak air kenitu merah bulat & 169,094 \\
& Ekstrak metanol kenitu hijau & 1279,156 \\
& bulat & \\
& Ekstrak metanol kenitu hijau & 550,116 \\
& lonjong & \\
& Ekstrak metanol kenitu merah & 426,118 \\
& bulat & \\
\hline
\end{tabular}

\section{PEMBAHASAN}

Pada pelaksanaan uji antiradikal bebas diawali dengan pembuatan spektra sinar tampak larutan uji untuk melihat apakah masih tampak adanya kurva normal (sigmoid) dengan puncak $517 \mathrm{~nm}$. Semua spektra larutan uji menunjukkan kurva normal dengan puncak $517 \mathrm{~nm}$. Pada menit ke60 larutan uji 2000 ppm ekstrak metanol kenitu merah bulat memberikan peredaman sempurna (100\%) yang ditunjukkan dengan perubahan warna ungu tua menjadi warna kuning sempurna, oleh karena itu tidak diikutkan dalam perhitungan $\mathrm{IC}_{50}$. Demikian juga pada ekstrak air kenitu merah bulat konsentrasi 2000 dan 1000 ppm pada menit ke-60 juga tidak diikutkan dalam perhitungan $\mathrm{IC}_{50}$. Harga $\mathrm{IC}_{50}$ umum digunakan untuk menyatakan aktivitas antioksidan suatu bahan uji dengan metode peredaman radikal bebas DPPH (Molyneux, 2004). Semakin kecil harga $\mathrm{IC}_{50}$, semakin besar aktivitas antioksidannya. Dari hasil penelitian ini dapat diketahui bahwa kenitu merah bulat memiliki aktivitas antioksidan terbesar, yang diikuti oleh kenitu hijau lonjong dan kenitu hijau bulat.

Secara umum, ekstrak air memiliki aktivitas antioksidan lebih besar daripada ekstrak metanol. Hal ini dikarenakan 
pada ekstrak air masih mengandung antioksidan larut air yakni vitamin $C$, selain senyawa polifenol antioksidan. Pada ekstrak metanol aktivitas antioksidan hanya ditentukan oleh senyawa golongan polifenol saja (Hidayat dan Umiyah, 2005). Untuk menguji aktivitas antioksidan senyawa polifenol ini lebih jauh, ekstrak metanol dapat dipartisi secara berurutan ke dalam heksana dan etil asetat. Di dalam fraksi etil asetat tersebut tidak terkandung senyawa antioksidan lain seperti vitamin $\mathrm{C}$ dan karoten, sehingga aktivitas antioksidannya hanya ditentukan oleh senyawa polifenol saja (Luo et al., 2002).

\section{KEPUSTAKAAN}

Anonim, 1994. Mengenal Tanaman Langka Indonesia. Penebar Swadaya.

Dyatmiko W dan Santosa MH, 1998. Aktivitas Antiradikal Bebas Difenilpikril Hidrazil (DPPH) Sari Air Curcuma aeruginosa Roxb., Seminar Nasional Tumbuhan Obat XIV, Bogor.

Heyne K, 1987. Tumbuhan Berguna Indonesia, Jilid III, diterjemahkan oleh Badan Litbang Kehutanan Jakarta, hal. 1558.

Hidayat MA dan Umiyah, 2005. Pengujian Antiradikal Bebas Difenilpikril Hidrazil (DPPH) Ekstrak Buah Kenitu (Chrysophyllum cainito L.) Dari Daerah Sekitar Jember, Simposium Nasional "Peningkatan Pemanfaatan Bahan Alam Dalam Penggunaan Klinis”, Fak. Farmasi Unika Widya Mandala Surabaya.

Leong LP dan Shui G, 2002. An Investigation of Antioxidant Capacity of Fruits in Singapore Markets, Food Chemistry 76: 69-75.
Luo XD, Basile MJ, dan Kennely EJ, 2002. Polyphenolic Antioxidants from Chrysophyllum cainito L. (Star Apple), Journal of Agricultural and Food Chemistry, Mar 13; 50(6): 13789-82.

Molyneux P, 2004. The use of the stable free radical diphenylpicrylhydrazyl (DPPH) for estimating antioxidant activity, Songklanakarin J. Sci. Technol., 26(2): 211-9.

Morton J, 1987. Star Apple, in: Morton, J., Fruits of Warm Climates, Miami Florida. 408-410.

Okawa M, Kinjo J, Nohara T, dan Ono M, 2001. DPPH (1,1Diphenyl-2-Picrylhydrazyl) Radical Scavenging Activity of Flavonoids Obtained from Some Medicinal Plants, Biol. Pharm. Bull, 24(10): 1202-5.

Prakash A, 2001. Antioxidant Activity, Medallion Laboratories Analytical Progress, 19(2).

Santosa HM, Budiati AS, Fuad A, dan Kusumawati I, 1998. Pengujian Antiradikal Bebas Difenilpikril Hidrazil (DPPH) Ekstrak Graptophyllum pictum (L). Griff. Secara Spektrofotometri, Seminar Nasional Tumbuhan Obat XIII, Malang.

USDA, NRCS, 2004. The Plants Database, Version 3.5 (http:// plants.usda.gov). National Plant Data Center, Baton Rouge, LA 70874-4490 USA.

Verheij EWM dan Coronel RE, 1992. Plant Resources of SouthEast Asia, No. 2, Edible fruits and nuts, PROSEA, Bogor Indonesia.

Wijaya A, 1996. Radikal Bebas dan Parameter Status Antioksidan, Forum Diagnosticum, Prodia Diagnostic Educational Services, No. 1: 1-12.

Reviewer: Dr. Pratiwi Puji Astuti, MSi. 